\title{
Amino Acid Profiles, Total Nitrogen Contents, and Computed-Protein Efficiency Ratios of Manihot esculenta Root and Dioscorea rotundata Tuber Peels
}

\author{
Paul Chidoka Chikezie, ${ }^{1}$ Chiedozie Onyejiaka Ibegbulem, ${ }^{2}$ Odinakachi Stella Monago, ${ }^{2}$ \\ Ferdinand Nkem Mbagwu, ${ }^{3}$ and Chibuike Udodi Nwachukwu ${ }^{4}$ \\ ${ }^{1}$ Department of Biochemistry, Imo State University, Owerri, Nigeria \\ ${ }^{2}$ Department of Biochemistry, Federal University of Technology, Owerri, Nigeria \\ ${ }^{3}$ Department of Plant Science and Biotechnology, Imo State University, Owerri, Nigeria \\ ${ }^{4}$ Department of Biology, Alvan Ikoku Federal College of Education, Owerri, Nigeria
}

Correspondence should be addressed to Paul Chidoka Chikezie; p_chikezie@yahoo.com

Received 23 June 2016; Accepted 19 October 2016

Academic Editor: Ma Murcia

Copyright (C) 2016 Paul Chidoka Chikezie et al. This is an open access article distributed under the Creative Commons Attribution License, which permits unrestricted use, distribution, and reproduction in any medium, provided the original work is properly cited.

\begin{abstract}
Tuberous roots of cassava and yam are major sources of dietary carbohydrate to human, alternative sources of energy in livestock feeds, and sources of starch in small-scale industries. Investigations on amino acid profiles, total nitrogen contents, and computedprotein efficiency ratios (C-PER) of tuberous root peels of Manihot esculenta Crantz and Dioscorea rotundata Poir. were carried out. Amino acid analysis was carried out using ion-exchange chromatography methods. Total nitrogen content was measured using the micro-Kjeldahl methods. The C-PER was calculated using regression equation. The concentrations of amino acids detected in the cassava peels ranged from 0.54 to $6.54 \mathrm{~g} / 100 \mathrm{~g}$ protein, whereas those of yam peels were between 0.37 and $6.25 \mathrm{~g} / 100 \mathrm{~g}$ protein. The total amino acid concentration of the cassava peels was not significantly $(p>0.05)$ higher than that of the yam peels. Essential amino acid scores showed that Phe + Tyr and Met + Cys were the most abundant and limiting amino acids, respectively, in cassava and yam peels. The percentage nitrogen content and C-PER of the cassava peels were significantly $(p<0.05)$ higher than those of the yam peels. The cassava and yam peels were not sources of good quality proteins. Therefore, the use of cassava or yam peels as livestock feeds should be supplemented with other sources rich in good quality proteins.
\end{abstract}

\section{Introduction}

L- $\alpha$-Amino acids are the primary sources of nitrogen atom for biological systems. They are precursors for the biosynthesis of nitrogenous compounds such as haem, purines, urea, pyrimidines, hormones, neurotransmitters, biological active peptides, and proteins $[1,2]$. Out of over 300 naturally occurring amino acids, precisely 20 amino acids are utilized in biologic systems to form vast arrays of protein molecules $[1,3]$. Nutrition scientists have shown that humans and other mammals lack the capability to synthesize around 10 of the $20 \mathrm{~L}-\alpha$-amino acids present in proteins in amounts adequate to support infant growth or to maintain wellbeing in adulthood. Consequently, diets for human and livestock must contain adequate quantities of these nutritionally essential amino acids, whereas the remaining nutritionally nonessential amino acids are readily biosynthesized from metabolic pathways involving amphibolic intermediates [2]. Amino acids such as Leu, Ile, Trp, Lys, Phe, and Tyr are termed ketogenic because they are precursors for the synthesize ketone bodies, namely, acetone, acetoacetate, and $\beta$ hydroxybutyrate, while Arg, Gln, His, Pro, Ile, Met, Thr, Val, Phe, Tyr, Asp, Asn, Ala, Cys, Gly, Ser, and Trp are termed glucogenic because they can be metabolized to glucose and glycogen. However, Ile, Trp, Tyr, and Phe are both ketogenic and glucogenic, whereas Lys and Leu are strictly ketogenic [4].

The dietary quantity and quality of proteins depend on the source of the food material. Dietary protein may exhibit varied physiochemical properties in terms of their 
digestibility and bioavailability as well as corresponding biologic value [5]. From nutritional standpoint, protein efficiency ratio (PER) defines the quotient between quantity of protein consumed and corresponding body weight gained by the animal. By derivation, computed-protein efficiency ratio (C-PER), as previously reported [6], describes a useful parameter for the evaluation of protein quality [7]. For the most part, the animal proteins are considered superior to those of plants because they can maintain body positive nitrogen balance by supplying all the essential amino acids even as the only source of nitrogen in the diet [8]. Additionally, plant proteins are generally not as well digested and assimilated when compared to animal proteins [9]. Nevertheless, studies have shown that proteins derived from plant products such as corn germ, soya bean, wheat germ, and yeast provide approximately the same proportion of amino acids as are supplied by animal proteins [10].

Overall, tuberous roots of Manihot esculenta Crantz (cassava) and Dioscorea rotundata Poir. (yam) are major sources of dietary carbohydrate to human, alternative sources of energy in livestock feeds, and sources of starch in smallscale industries [11-15]. Report according to Okigbo [16] noted that cassava root peels contained slightly more protein than was present in the starchy parenchyma portion of whole root. Some cassava-based products known by their local names include abacha, fufu, farinha, lio-lio, tapioca, and garri. The tropical belt in African produces more cassava roots than the rest of the world put together, with production level that scaled over 230 million metric tonnes in 2010 [17].

A transverse section of cassava root reveals three distinct layers [18-20]. The outermost layer or peridermal region of the cassava root weighs about $0.5-2.0 \%$ of the total wet root weight. The cortical parenchyma measures between 1 and $2 \mathrm{~mm}$ thick and contains most of the cyanogenic glycosides present in cassava root. The early step of processing cassava root into various products involves manual removal of its outer cover using a knife.

Yam tuber is usually cylindrical in shape and weighs 3$5 \mathrm{~kg}$. However, the shape and size may vary due to genetic and environmental factors [19]. Although there are over 200 species of yams, only 10 species are sources of staple food in the tropics [21, 22]. In 2005, five million hectares in about 47 countries worldwide produced 48.7 million metric tonnes of yams, of which $97 \%$ of the produce was in Sub-Saharan Africa [23]. Yams are often eaten boiled, fried, and roasted or pounded into white paste or dark brown paste called Amala in southern Nigeria, which is a popular local delicacy in Yoruba land made from yam powder. Like other tuber and root crops, processing of yam tubers begins with removal of the outer cover using a knife. The nutrient composition and energy values of yam varieties have been described elsewhere [24]. The transverse section of a mature yam tuber as described $[19,25]$ reveals an outer portion or corky periderm and inner cortex beneath the periderm, which contains small quantity of stored starch. The meristematic layer is comprised of thinwall of cells from which sprouts are initiated. The ground tissues are repositories to the vascular bundles and vast number of starchy cells. The yam peels are mostly comprised of the corky periderm, cortex, and meristematic layer.
One of several measures to overcoming the major challenges of food security in Nigeria involves maximum utilization of food crops, in which the by-products and wastes generated during the processing stage are transformed into useful and consumable products. In animal husbandry, cassava and yam peels are cheap sources of feeds for livestock [15, 26, 27]. Ruminants digest the fibre content of the peels using mutualistic microorganisms into methane, $\mathrm{CO}_{2}$, acetic, and propionic and butyric acids, which are absorbed by the animal (host) as a major source of energy [28]. However, in the agrobased small-scale industries, the impact of cassava peels on environmental pollution [29-32] underscores the necessity to convert these wastes to useful products, which serves to increase the food and economic values of cassava roots and, by extension, yam tubers. Accordingly, investigations on the amino acid profile, total nitrogen content, and C-PER of tuberous root peels of M. esculenta and D. rotundata were carried out in order to establish their collective potential to serve as readily available sources of dietary amino acids and quality proteins for maintenance of body positive nitrogen balance.

\section{Materials and Methods}

2.1. Collection of Cassava and Yam Samples. Matured and healthy roots of the "bitter" cassava variety ( $M$. esculenta) and "white" yam variety (D. rotundata Poir.) were harvested during the wet season, on 16 August, 2015, from Ofkaja Farm at Uruagu-Nnewi, Anambra State (latitude $6^{\circ} 20^{\prime} \mathrm{N}$; longitude $7^{\circ} 00^{\prime} \mathrm{E}$ ), Nigeria, which lies on the rainforest belt. The cassava roots and yam tubers were transported to the laboratory within $24 \mathrm{~h}$, identified, and authenticated by Dr. F. N. Mbagwu at the Herbarium of the Department of Plant Science and Biotechnology, Imo State University, Owerri, Nigeria. The samples have voucher numbers IMSUH 076 and IMSUH 116 for the yam tubers and cassava roots, respectively.

2.2. Peeling and Drying. The cassava roots and yam tubers were washed under continuous current of tap water for 5 min to remove soil matter and thereafter mopped dry using blotting papers. The outer cover of the cassava roots and yam tubers were manually removed using a stainless kitchen knife. The cassava and yam peels were collected separately on stainless-steel trays and oven-dried (Gallenkamp Oven 300 plus series, England) at $150^{\circ} \mathrm{C}$ for $24 \mathrm{~h}$. The samples were heated at such a temperature because denaturation of proteins by heat affects primarily the hydrogen bonds without breaking the covalent bonds in the polypeptide [4]. The dried peels were cooled to ambient room temperature $(T=25 \pm$ $5^{\circ} \mathrm{C}$ ), ground into powder, and stored in sterile glass jars with screw caps until used for further analyses.

2.3. Analysis for Amino Acid Composition. Amino acid analysis was carried out using ion-exchange chromatography (IEC) as described by Spackman et al. [33], Ibegbulem et al. [34], and Ibegbulem and Belonwu [35]. The samples were defatted, acid digested before dispensing the digest into the amino acid analyzer. Briefly, the dried cassava and yam peels were defatted according to standard methods [36]. A quantity $(6 \mathrm{~g})$ of the pulverized cassava peels was weighted 
and transferred into an extraction thimble. The extraction of the lipid soluble matter of the peels was carried out using chloroform/methanol $(2: 1 ; \mathrm{v} / \mathrm{v})$ mixture in a Soxhlet extraction apparatus. Then, $4 \mathrm{~g}$ of the defatted pulverized peels was transferred into a glass ampoule. A volume $(8 \mathrm{~mL})$ of $6 \mathrm{~N} \mathrm{HCl}$ was added to the sample and oxygen expelled from the vicinity of the sample/acid mixture by passing gaseous nitrogen into the glass ampoule. The ampoule was sealed over a Bunsen burner flame, transferred into an oven (Gallenkamp Oven 300 plus series, England), preset at $105 \pm 5^{\circ} \mathrm{C}$, and allowed to stand for $22 \mathrm{~h}$. Thereafter, the ampoule was allowed to cool to ambient room temperature, the content released by breaking the tip and filtered using Whatman No 52 filter paper [37]. The filtrate was evaporated to dryness in a hot air oven (Gallenkamp Oven 300 plus series, England). Finally, the residue was dissolved in $5 \mathrm{~mL}$ acetate buffer $(\mathrm{pH}=2.0)$ and stored in a plastic tube at freezing temperature of $-4^{\circ} \mathrm{C}$ until used for analyses. A volume of $10 \mu \mathrm{L}$ of the digest was dispensed into the cartridge of Technicon Sequential Multisample (TSM) amino acid analyzer (Technicon Instruments Corporation, New York). The automated analysis lasted for $76 \mathrm{~min}$. The entire procedure was repeated for the pulverized yam peels. The concentration of each free amino acid was proportional to the peak area marked out by an integrator attached to the TSM analyzer.

2.4. Resolution of Asp, Asn, Glu, and Gln Contents of Sample. The contents of Asp and Asn as well as Glu and Gln were resolved as described by Ibegbulem [39] and Ibegbulem et al. [34] using the ratio of 5.3/4.3 for Asp to Asn and 6.3/4.2 for Glu to Gln. Amino acids like Asp, Asn, Glu, and Gln have average percentage occurrence of $5.3,4.3,6.3$, and 4.2 , respectively, in 1150 proteins of known amino acid sequences (Nelson and Cox, 2008). The total Glu (Glx) and total Asp (Asx) contents estimated for the cassava and yam peels were 6.54 and 6.00 , respectively, and 6.25 and 5.81, respectively.

2.5. Computation of Amino Acid Groupings. The computation of the total amino acid (TAA), total essential amino acid (TEAA), total nonessential amino acid (TNEAA), total acidic amino acid (TAAA), and total basic amino acid (TBAA) of a sample was calculated as described by Ibegbulem et al. [34]. Total glucogenic amino acid (TGAA) was calculated by summing up the concentrations of Arg, Gln, His, Pro, Met, Thr, Val, Asp, Asn, Ala, Cys, Gly, and Ser while the total ketogenic amino acids (TKAA) were calculated by summing up the Lys and Leu contents of the samples. Trp was not used in the computations because it is normally destroyed during such chemical analysis $[4,34,35]$.

2.6. Percentage Amino Acid/TAA Ratio. This was calculated as the ratio of the concentration of the amino acid to TAA multiplied by 100 .

2.7. Chemical Scores of Essential Amino Acids. The essential amino acid (EAA) score of an EAA was calculated as the ratio of the concentration of that EAA (mg/g protein) to that of its desired concentration $(\mathrm{mg} / \mathrm{g}$ protein) in a reference food
TABLE 1: Amino acid profile ( $\mathrm{g} / 100 \mathrm{~g}$ protein) of cassava and yam peels.

\begin{tabular}{lccccc}
\hline Amino acid & Cassava peels & Yam peels & Mean & SD & $\% \mathrm{CV}$ \\
\hline Lys $^{\mathrm{c}}$ & 2.42 & 2.36 & 2.30 & 0.03 & 1.26 \\
$\mathrm{His}^{\mathrm{c}}$ & 1.08 & 0.95 & 1.02 & 0.07 & 6.40 \\
$\mathrm{Arg}^{\mathrm{c}}$ & 3.23 & 3.15 & 3.19 & 0.04 & 1.25 \\
$\mathrm{Thr}^{\mathrm{c}}$ & 2.27 & 2.16 & 2.22 & 0.06 & 2.70 \\
$\mathrm{Met}^{\mathrm{c}}$ & 0.54 & 0.37 & 0.46 & 0.09 & 19.57 \\
$\mathrm{Ile}^{\mathrm{c}}$ & 3.13 & 1.70 & 2.42 & 0.72 & 29.75 \\
$\mathrm{Phe}^{\mathrm{c}}$ & 2.82 & 2.29 & 2.56 & 0.27 & 10.55 \\
Leu $^{\mathrm{c}}$ & 4.17 & 3.58 & 3.88 & 0.30 & 7.75 \\
$\mathrm{Val}^{\mathrm{c}}$ & 3.10 & 3.16 & 3.13 & 0.33 & 0.95 \\
$\mathrm{Asp}^{\mathrm{b}}$ & 3.31 & 3.21 & 3.26 & 0.05 & 1.53 \\
$\mathrm{Asn}^{\mathrm{b}}$ & 2.69 & 2.60 & 2.65 & 0.05 & 1.89 \\
$\mathrm{Ser}^{\mathrm{b}}$ & 1.59 & 1.41 & 1.50 & 0.09 & 6.00 \\
$\mathrm{Glu}^{\mathrm{b}}$ & 3.92 & 3.75 & 3.84 & 0.09 & 2.34 \\
$\mathrm{Gln}^{\mathrm{b}}$ & 2.62 & 2.50 & 2.56 & 0.06 & 2.34 \\
Pro $^{\mathrm{b}}$ & 1.62 & 1.39 & 1.51 & 0.12 & 7.95 \\
$\mathrm{Gly}^{\mathrm{b}}$ & 2.40 & 2.41 & 2.41 & 0.00 & 0.00 \\
$\mathrm{Ala}^{\mathrm{b}}$ & 3.31 & 3.31 & 3.31 & 0.00 & 0.00 \\
Cys $^{\mathrm{b}}$ & 0.55 & 0.41 & 0.48 & 0.07 & 14.50 \\
Tyr $^{\mathrm{b}}$ & 1.99 & 1.90 & 1.95 & 0.05 & 2.56 \\
\hline $\mathrm{V}^{\mathrm{b}}$ & & &
\end{tabular}

Values are means of triplicate determinations; c = essential amino acids; $\mathrm{b}=$ nonessential amino acids; $\mathrm{SD}=$ standard deviation; $\mathrm{CV}=$ coefficient of variation.

protein $[34,35,40]$. The FAO/WHO/UNU [38] amino acid scores were used as standard reference values.

2.8. Total Nitrogen Content. The total nitrogen contents of the cassava and yam peels were measured using the microKjeldahl methods as previously described [36].

2.9. Computation of Protein Efficiency Ratio. The C-PER was calculated using the regression equation described by Alsmeyer et al. [6]:

$$
\mathrm{C}-\mathrm{PER}=-0.684+0.456[\mathrm{LEU}]-0.047[\mathrm{PRO}] .
$$

2.10. Statistical Analysis. The results were expressed as mean \pm SD, statistically analyzed using one-way ANOVA, and the level of significance was set at $p<0.05$. The data were also analyzed using the percentage coefficient of variation $(\% \mathrm{CV})$.

\section{Results}

The concentrations of the various amino acids detected in the cassava peels ranged from 0.54 to $6.54 \mathrm{~g} / 100 \mathrm{~g}$ protein, whereas those of yam peels were between 0.37 and $6.25 \mathrm{~g} / 100 \mathrm{~g}$ protein (Table 1). Furthermore, the results in Table 1 showed that cassava and yam peels contained comparatively high concentrations of Leu and Glu, respectively, whereas Met and Cys concentrations were relatively low. There was no disparity in amino acids concentrations between the cassava and yam peels with respect to Gly 
TABLE 2: Average amino acid groupings of cassava and yam peels and some ratios.

\begin{tabular}{|c|c|c|c|c|c|}
\hline Groups & Cassava peels & Yam peels & Mean & SD & $\% \mathrm{CV}$ \\
\hline TAA (g/100 g protein) & 46.76 & 42.61 & 44.69 & 2.08 & 4.65 \\
\hline TNEAA (g/100 g protein) & 24.00 & 22.89 & 23.45 & 0.56 & 2.39 \\
\hline TEAA (g/100 g protein) & 22.76 & 19.72 & 21.24 & 1.52 & 7.16 \\
\hline TAAA (g/100 g protein) & 7.23 & 6.96 & 7.10 & 0.14 & 1.97 \\
\hline TBAA (g/100 g protein) & 6.73 & 6.46 & 6.60 & 0.14 & 2.12 \\
\hline TGAA (g/100 g protein) & 28.31 & 27.03 & 27.67 & 0.64 & 2.31 \\
\hline TKAA (g/100 g protein) & 6.59 & 5.94 & 6.27 & 0.33 & 5.26 \\
\hline TEAA/TAA ratio & 0.49 & 0.46 & 0.48 & 0.12 & 25.00 \\
\hline TNEAA/TAA ratio & 0.51 & 0.54 & 0.53 & 0.12 & 22.64 \\
\hline TNEAA/TEAA ratio & 1.05 & 1.86 & 1.46 & 0.40 & 27.40 \\
\hline TAAA/TBAA ratio & 1.07 & 1.08 & 1.08 & 0.01 & 0.93 \\
\hline TGAA/TKAA ratio & 4.30 & 4.55 & 4.43 & 0.03 & 0.68 \\
\hline$\%$ Pro/TAA ratio & 3.46 & 3.26 & 3.36 & 0.10 & 2.98 \\
\hline \%Gly/TAA ratio & 5.13 & 5.66 & 5.40 & 0.27 & 5.00 \\
\hline
\end{tabular}

and Ala. In contrast, the variability in Ile concentrations between the cassava and yam peels was relatively very high as exemplified by the \%CV $=29.75$. Additionally, \%CV of His, Met, Ser, Leu, Pro, Cys, and Phe concentrations between the cassava and yam peels were moderately high.

The total amino acids (TAA) concentration of the cassava peels was not significantly $(p>0.05)$ higher than those of the yam peels (Table 2). Likewise, the total nonessential amino acids (TNEAA) concentration of the cassava peels was not higher than those of the yam peels.

Table 2 showed that the yam peels exhibited relatively lower concentrations of total essential amino acids (TEAA) than those of the cassava peels. The ratios of TEAA or TNEAA to TAA, TNEAA to TEAA, and \%Gly/TAA between cassava and yam peels were significantly different $(p<0.05)$. However, the ratios of either TAAA to TBAA, TGAA to TKAA, and \%Pro/TAA between cassava and yam peels were not significantly different $(p>0.05)$.

The values of the TEAA, TKAA, and TEAA/TAA ratios of the cassava peels were significantly $(p<0.05)$ higher than those of the yam peels, whereas the TNEAA/TAA and TNEAA/TEAA ratios of the yam peels were significantly $(p<$ 0.05 ) higher than those of the cassava peels (Table 2). The average amino acid concentrations, in the cassava and yam peels, according to their groups were in the order: TGAA > TNEAA $>$ TEAA $>$ TAAA $>$ TBAA $>$ TKAA.

The Met + Cys, Ile, Leu, and Phe + Tyr essential amino acid scores of the cassava peels were significantly $(p<0.05)$ higher than those of the yam peels (Table 3 ). The TEAA score of cassava peels was significantly $(p<0.05)$ higher than those of the yam peels.

Table 4 showed that the percentage nitrogen content $(\% \mathrm{~N})$ and C-PER value of the cassava peels were significantly higher than those of the yam peels.
TABLE 3: Essential amino acid scores of cassava and yam peels relative to provisional amino acid scoring pattern.

\begin{tabular}{lcccccc}
\hline & Amino & \multicolumn{5}{c}{$\begin{array}{c}\text { Amino acid scores }(\mathrm{mg} / \mathrm{g} \\
\text { protein) }\end{array}$} \\
acid & $\begin{array}{c}{ }^{*} \text { Standard } \\
\text { value }\end{array}$ & $\begin{array}{c}\text { Cassava } \\
\text { peels }\end{array}$ & Yam peels & Mean & SD & $\%$ CV \\
\hline Lys & 55 & 0.44 & 0.43 & 0.44 & 0.01 & 2.27 \\
Thr & 40 & 0.57 & 0.54 & 0.56 & 0.02 & 3.57 \\
Met + Cys & 35 & 0.31 & 0.22 & 0.27 & 0.05 & 18.52 \\
Ile & 40 & 0.78 & 0.43 & 0.61 & 0.18 & 29.51 \\
Leu & 70 & 0.60 & 0.51 & 0.56 & 0.05 & 8.93 \\
Val & 50 & 0.62 & 0.63 & 0.63 & 0.01 & 1.59 \\
Phe + Tyr & 60 & 0.80 & 0.70 & 0.75 & 0.05 & 6.66 \\
\hline Total & 360 & 4.12 & 3.46 & 3.79 & 0.33 & 8.71 \\
\hline
\end{tabular}

$\mathrm{SD}=$ standard deviation; $\mathrm{CV}=$ coefficient of variation; ${ }^{*}$ standard value of essential amino acid scores according to $\mathrm{FAO} / \mathrm{WHO} / \mathrm{UNU}$ [38].

TABle 4: Percentage nitrogen contents and computed-protein efficiency ratios of cassava and yam peels.

\begin{tabular}{lccccc}
\hline Parameter & Cassava peels & Yam peels & Mean & SD & $\% \mathrm{CV}$ \\
\hline$\% \mathrm{~N}$ & $3.33 \pm 0.07^{\mathrm{a}}$ & $1.17 \pm 0.09^{\mathrm{b}}$ & 2.25 & 0.08 & 6.40 \\
$\mathrm{C}-\mathrm{PER}$ & 1.14 & 0.88 & 1.01 & 0.13 & 12.87 \\
\hline
\end{tabular}

$\% \mathrm{~N}=$ percentage nitrogen; C-PER = computed-protein efficiency ratio; $\mathrm{SD}=$ standard deviation; $\mathrm{CV}=$ coefficient of variation. Data on same row with different superscript letters are significantly different $(p<0.05)$.

\section{Discussion}

Previous reports had shown that tuberous roots of cassava and yam contain relatively low amounts of proteins that were 
within the range of $1-4 \%[41,42]$. However, protein content of the tuberous roots may vary considerably among different species and cultivar depending on climatic, edaphic, and growth conditions as well as level of maturity at harvest [4244]. The outcome of the amino acid profiles of the present study (Table 1) showed that Leu and Glu were, comparatively, the most abundant amino acids in cassava and yam peels, respectively. The relative high concentrations of Glu in yam peels conformed to previous reports on the distribution of the amino acid in two cultivars of $D$. rotundata tubers undergoing storage [42] and matured M. esculenta roots [45]. Earlier reports had noted that the total nitrogen content of cassava roots accounted for about $50 \%$ of the crude protein content, whereas the other $50 \%$ comprised free amino acids, which were predominantly Glu and Asp, and nonprotein components such as nitrite, nitrate, and cyanogenic compounds $[44,46,47]$. The level of disparity in amino acids contents between cassava and yam peels were such that Cys, Met, Phe, and Ile concentrations exhibited double-digit variability, whereas those of Ser, His, Leu, and Pro exhibited singledigit variability as exemplified by their corresponding \%CVs (Table 1). Nevertheless, the protein quality of cassava peels was better than those of the yam peels (Table 4) due to its higher Pro and Leu contents (Table 1) as expressed in (1) and defined by C-PER.

The ratios of TAAA to TBAA and TGAA to TKAA between cassava and yam peels (Table 2) suggested that their proteins were more negatively charged and that more than fourfold of the ketogenic amino acids contents can be used to synthesize glucose and glycogen. The \%Pro/TAA ratios and \%Gly/TAA ratios indicated that cassava and yam peels contained globular proteins. Fibrous proteins like collagen contain 33\% Gly and 13\% Pro, whereas globular proteins like haemoglobin contain 4\% Gly and 5\% Pro [48].

The aromatic amino acids were the most abundant essential amino acids in the peels (Table 3) but fell short of meeting adequate nutritional requirements by 20 and $30 \%$ for cassava and yam peels, respectively. Conversely, the present findings showed that Met + Cys had the least essential amino score in the tuberous roots peels of cassava and yam, respectively, exemplified by their relatively low levels (Table 1 ). This result corroborated previous reports $[42,46,49,50]$. The sulphurcontaining amino acids, Met + Cys, fell short of meeting adequate nutritional requirement by 69 and $78 \%$ in cassava and yam peels, respectively. Previous reports showed that Leu had the lowest essential amino acid score in heattreated fresh palm wines from Raphia hookeri and Elaeis guineensis [34], whereas Thr had the lowest essential amino acid score in process-line cocoa nibs and processed cocoa cake samples [50]. However, the vagaries of intermediary metabolism, especially in tuberous roots during storage or sprouting, may prompt wide variability in their amino acids concentrations and distribution [42]. Since the peels contained all the essential amino acids, their amino acids contents can be used to synthesize proteins with strikingly different properties and activities unlike those of palm kernel oil which did not contain essential amino acids like Ile, Thr, and Val [35]. The corrections for the sulphur-containing amino acids in the peels were calculated to be $1 / 0.31$ or
3.23 times and $1 / 0.22$ or 4.55 times the protein contents of cassava and yam peels, respectively. Specifically, their protein contents were 20.81 and $7.31 \%$ for the cassava and yam peels, respectively, if their $\% \mathrm{~N}$ contents (Table 4 ) are multiplied by the conversion factor of 6.25 . These were indications that the cassava peels were of better protein quality than the yam peels, especially since it contained more essential amino acids. However, earlier reports $[43,51,52]$ had indicated that yam species such as $D$. dumetorum (bitter yam) and D. trifida contained comparatively higher protein concentrations, which, by implication, contained higher quantity of TAA compared with $D$. rotundata. Incidentally, yam species noted to contain relative high protein concentrations which were correspondingly rich in alkaloids [41].

The higher percentage of nitrogen in cassava peels than that of the yam peels (Table 4) may be connected to the presence of comparatively more nonprotein nitrogen elements derived from nitrite, nitrate, cyanogenic glycosides, and hydrocyanic acid $(\mathrm{HCN})$ in cassava roots [46], since the total amino acids concentrations of cassava and yam peels exhibited no significant difference (Table 2). The C-PER of cassava peel was higher that of yam peels, suggesting that it is more nutritious. However, the C-PER indices of cassava and yam peels were lower than those of whole body, flesh, and exoskeleton of Sudananautes africanus africanus (West African freshwater male crab) and other animal proteins $[53,54]$. The minimum threshold index of C-PER for good quality protein was reported to be 1.50 [10]. Plant proteins that have been noted to be of good quality in this regard include those from groundnuts: C-PER $=2.62$ [55], pigeon pea: $C$ PER $=1.82$ [56], raw and heat-treated fruits of Canarium schweinfurthii (African elemi): C-PER $=1.69-2.10$ [57], and millet ogi: C-PER $=1.62$ [58]. Therefore, the findings of the present study did not qualify proteins from cassava and yam peels to be of good quality by virtue of their CPER indices. Nonetheless, cassava and yam peels were better protein sources than palm kernel oil $[35,59]$. However, the use of cassava or yam peels as livestock feeds are usually supplemented with other sources that are rich in good quality proteins or are subjected to biofortification and protein enrichment as previously described [12, 26, 32, 46, 60-62].

\section{Conclusion}

The present study showed that cassava and yam peels had relatively low protein content. The amino acid profile of the peels of cassava roots and yam tuber indicated that Leu and Glu were the most abundant amino acids, whereas Met and Cys were the limiting amino acids. Cassava peels contained higher levels of nitrogenous elements than yam peels. The CPER indices did not qualify proteins from cassava and yam peels to be of good quality. Accordingly, the use of cassava or yam peels as livestock feeds should be supplemented with other sources rich in good quality proteins or subjected to biofortification and protein enrichment.

\section{Competing Interests}

The authors declare that there is no conflict of interests regarding the publication of this article. 


\section{Acknowledgments}

The authors are grateful for the technical assistance offered by Mr. O. A. K. Emenyonu, Chief Academic Technologist, Department of Biochemistry, Imo State University, Owerri.

\section{References}

[1] V. W. Rodwell, "Amino acids and peptides," in Harper's Review of Biochemistry, D. W. Martin, P. A. Mayes, and V. W. Rodwell, Eds., pp. 14-30, Lange Medical Books/McGraw-Hill, Rosehill, Calif, USA, 1983.

[2] V. W. Rodwell and P. J. Kennelly, "Amino acids and peptides," in Harper's Illustrated Biochemistry, R. K. Murray, D. K. Granner, P. A. Mayes, and V. W. Rodwell, Eds., pp. 14-20, Lange Medical Books/McGraw-Hill, Los Altos, Calif, USA, 2003.

[3] B. Alberts, A. Johnson, and J. Lewis, Molecular Biology of the Cell, The Shape and Structure of Proteins, Garland Science, New York, NY, USA, 4th edition, 2002.

[4] D. L. Nelson and M. M. Cox, Lehninger Principles of Biochemistry, W.H. Freeman and Company, New York, NY, USA, 6th edition, 2008.

[5] Z. A. Bhutta and K. Sadiq, "Protein digestion and bioavailability," in Reference Module in Biomedical Sciences Encyclopedia of Human Nutrition, pp. 116-122, Elsevier, Chennai, India, 3rd edition, 2013.

[6] R. H. Alsmeyer, A. E. Cunningham, and M. I. Happich, "Equations to predict PER from amino acid analysis," Food Technology, vol. 28, pp. 34-38, 1974.

[7] FAO/WHO, Joint FAO/WHO Food Standards Programme, Codex Alimentarius Commission XII, Supplement 4, Report of the Food and Agricultural Organization of the United Nations, Rome, Italy, 1991.

[8] F. Kummerow, Protein: Building Blocks of the Body, Weston A. Price Foundation, 2011, http://www.westonaprice.org/healthtopics/abcs-of-nutrition/protein-bui.

[9] V. R. Young and P. L. Pellett, "Plant proteins in relation to human protein and amino acid nutrition," American Journal of Clinical Nutrition, vol. 59, no. 5, pp. 1203-1212, 1994.

[10] M. Friedman, "Nutritional value of proteins from different food sources: a review," Journal of Agricultural and Food Chemistry, vol. 44, no. 1, pp. 6-29, 1996.

[11] S. A. Osei, M. Asiamah, and C. C. Atuahene, "Effects of fermented cassava peel meal on the performance of layers," Animal Feed Science and Technology, vol. 29, no. 3-4, pp. 295301, 1990.

[12] C. E. Okpako, V. O. Ntui, A. N. Osuagwu, and F. I. Obasi, "Proximate composition and cyanide content of cassava peels fermented with Aspergillus niger and Lactobacillus rhamnos," Journal of Food, Agriculture and Environment, vol. 6, no. 2, pp. 251-255, 2008.

[13] J. Yang, D. An, and P. Zhang, "Expression profiling of cassava storage roots reveals an active process of glycolysis/gluconeogenesis," Journal of Integrative Plant Biology, vol. 53, no. 3, pp. 193-211, 2011.

[14] D. F. Apata and T. O. Babalola, "The use of cassava, sweet potato and cocoyam, and their by-products by non-ruminants," International Journal of Food Science and Nutrition Engineering, vol. 2, no. 4, pp. 54-62, 2012.

[15] B. Lukuyu, I. Okike, A. Duncan, M. Beveridge, and M. Blümmel, Use of Cassava in Livestock and Aquaculture Feeding
Programs, ILRI Discussion Paper 25, International Livestock Research Institute, Nairobi, Kenya, 2014.

[16] B. N. Okigbo, "Nutritional implications of projects giving high priority to the production of staples of low nutritive quality. In the case for cassava (Manihot esculenta Crantz) in the humid tropics of West Africa," Food Nutrition Bulletin, vol. 2, pp. 1-10, 1980.

[17] FAO, Agricultural Statistics, Report of the Food and Agriculture Organization of the United Nations, Rome, Italy, 2012.

[18] O. O. Tewe, "Detoxification of Cassava Products and Effects of Residual Toxins on Consuming Animals," FAO Corporate Document: Roots, tubers, and bananas in animal feeding, Rome, 2016, http://www.fao.org/docrep/003/T0554E/T0554E06.htm.

[19] P. Q. Craufurd, R. J. Summerfield, R. Asiedu, and P. V. Vara Prasad, "Dormancy in yams," Experimental Agriculture, vol. 37, no. 2, pp. 147-181, 2001.

[20] V. Lebot, Tropical Root and Tuber Crops: Cassava, Sweet Potato, Yams, Aroids, CAB International, Oxfordshire, UK, 2009.

[21] FAO, Report of the Food and Agriculture Organization of the United Nations (FAO), FAOSTAT, Rome, Italy, 2005.

[22] A. Sartie, R. Asiedu, and J. Franco, "Genetic and phenotypic diversity in a germplasm working collection of cultivated tropical yams (Dioscorea spp.)," Genetic Resources and Crop Evolution, vol. 59, no. 8, pp. 1753-1765, 2012.

[23] FAO, FAO Statistics 2009, Report of the Food and Agricultural Organization of the United Nations, Rome, Italy, 2009.

[24] D. Polycarp, E. O. Afoakwa, A. S. Budu, and E. Otoo, "Characterization of chemical composition and anti-nutritional factors in seven species within the Ghanaian yam (Dioscorea) germplasm," International Food Research Journal, vol. 19, no. 3, pp. 985-992, 2012.

[25] I. C. Onwueme, The Tropical Tuber Crops: Yam, Cassava, Sweet Potato and Cocoyams, John Wiley \& Sons, London, UK, 1978.

[26] T. A. Afolabi, R. S. Onadeji, O. A. Ogunkunle, and F. O. Bamiro, "Comparative analysis of the nutritional quality of browse leaves (Spondias mombin and Albizia saman) and tuber peels (yam and cassava) used as ruminant feeds," Ife Journal of Science, vol. 14, no. 2, pp. 337-344, 2012.

[27] I. C. Okoli, C. O. Okparaocha, C. E. Chinweze, and A. B. I. Udedibie, "Physicochemical and hydrogen cyanide content of three processed cassava products used for feeding poultry in Nigeria," Asian Journal of Animal and Veterinary Advances, vol. 7, no. 4, pp. 334-340, 2012.

[28] D. J. Taylor, N. P. O. Green, and G. W. Stout, "Heterotrophic nutrition," in Biological Science, R. Soper, Ed., pp. 227-263, Cambridge University Press, Cambridge, Mass, USA, 3rd edition, 1997.

[29] A. N. Jyothi, B. N. Sasikiran, and C. Balagopalan, "Optimization of glutamic acid production from cassava starch factory residues using Brevibacterium divaricatum," Process Biochemistry, vol. 40, no. 11, pp. 3576-3579, 2005.

[30] G. Oboh, "Nutrient enrichment of cassava peels using a mixed culture of Saccharomyces cerevisae and Lactobacillus spp solid media fermentation techniques," Electronic Journal of Biotechnology, vol. 9, no. 1, pp. 46-49, 2006.

[31] A. E. Cumbana, E. Mirione, J. Cliff, and J. H. Bradbury, "Reduction of cyanide content of cassava flour in Mozambique by the wetting method," Food Chemistry, vol. 101, no. 3, pp. 894897, 2007.

[32] O. O. Ezekiel, O. C. Aworh, H. P. Blaschek, and T. C. Ezeji, "Protein enrichment of cassava peel by submerged fermentation 
with Trichoderma viride (ATCC 36316)," African Journal of Biotechnology, vol. 9, no. 2, pp. 187-194, 2010.

[33] D. H. Spackman, W. H. Stein, and S. Moore, "Automatic recording apparatus for use in chromatography of amino acids," Analytical Chemistry, vol. 30, no. 7, pp. 1190-1206, 1958.

[34] C. O. Ibegbulem, C. U. Igwe, G. N. Okwu, C. O. Ujowundu, E. N. Onyeike, and E. O. Ayalogu, "Total amino acid profiles and essential amino acid scores of heat-processed fresh Elaeis guineensis and Raphia hookeri wines," Food Chemistry, vol. 138, no. 2-3, pp. 1616-1620, 2013.

[35] C. O. Ibegbulem and D. C. Belonwu, "Phytosterol and amino acid profiles of palm kernel oil: possible metabolic implications," Journal of Investigational Biochemistry, vol. 3, no. 1, pp. 32-36, 2014.

[36] AOAC, Official Method of Analysis, Association of Official Analytical Chemist, Washington, DC, USA, 18th edition, 2006.

[37] E. N. Onyeike, E. O. Ayalogu, and C. C. Okaraonye, "Nutritive value of the larvae of raphia palm beetle (Oryctes rhinoceros) and weevil (Rhyncophorus pheonicis)," Journal of the Science of Food and Agriculture, vol. 85, no. 11, pp. 1822-1828, 2005.

[38] FAO/WHO/UNU, Amino Acid Scoring Patterns, Joint FAO/ WHO/UNU Expert Consultation on Energy and Protein Requirements, Provisional Agenda Item 3.2.3, Food and Agriculture Organization/World Health Organization/United Nations University ESN: FAO/WHO/UNU EPR/81/31, Report of the Food and Agriculture Organization of the United Nations, Rome, 1981.

[39] C. O. Ibegbulem, "Nutritional effects of drinking Terminalia lottoralis Seem decoction," International Journal of Biochemistry Research and Review, vol. 2, no. 4, pp. 126-136, 2012.

[40] G. M. Wardlaw and M. W. Kessel, Food Composition Tables. In Perspective in Nutrition, Mc-Graw Hill, Boston, Mass, USA, 5th edition, 2002.

[41] A. U. Osagie, The yam tuber in storage[M.S. thesis], Post Harvest Research Unit, University of Benin, Benin, Nigeria, 1992.

[42] H. R. Adeyemi and O. B. Oloyede, "Assessment of protein and metabolites in two cultivars of Dioscorea rotundata (yam) undergoing storage," International Journal of Science and Nature, vol. 2, no. 4, pp. 782-786, 2011.

[43] A. Bell and J. C. Favier, "Effect of traditional food processing methods on the nutritional value of yam in cameroon," in Proceedings of the Tropical Root Crops: Research Strategy for the 1980's International Development Research Center, pp. 214-224, Ottawa, Canada, September 1980.

[44] H.-H. Yeoh and V.-D. Truong, "Protein contents, amino acid compositions and nitrogen-to-protein conversion factors for cassava roots," Journal of the Science of Food and Agriculture, vol. 70, no. 1, pp. 51-54, 1996.

[45] J. L. Gil and A. J. A. Buitrago, "La yuca en la alimentacion," in La Yuca en el Tercermilenio: Sistemasmodernos de Producción, Procesamiento, Utilización y Comercialización, B. Ospina and $\mathrm{H}$. Ceballos, Eds., pp. 527-569, Centro Internacional de Agricultura Tropical, Cali, Colombia, 2002.

[46] J. A. Montagnac, C. R. Davis, and S. A. Tanumihardjo, "Nutritional value of cassava for use as a staple food and recent advances for improvement," Comprehensive Reviews in Food Science and Food Safety, vol. 8, no. 3, pp. 181-194, 2009.

[47] OECD, Consensus document on compositional considerations for new varieties of cassava (Manihot esculenta Crantz): Key
Food and Feed Nutrients, Anti-Nutrients, Toxicants and Allergens, Organization for Economic Growth and Development Website, https://www.oecd.org/science/biotrack/46815306.pdf.

[48] R. M. Schultz and M. N. Liebman, "Proteins I: composition and structure," in Textbook of Biochemistry with Clinical Correlations, T. M. Devlin, Ed., pp. 75-132, Wiley-Liss, New Jersey, NJ, USA, 6th edition, 2006.

[49] FAO, The Role of Roots, Tubers and Plantains in Food Security in Sub-Sahara Africa, Latin America and the Caribbean, and in the Pacific (FAO Social and Economic Development Study), Report of the Food and Agricultural Organization of the United Nations, Rome, Italy, 1989.

[50] E. I. Adeyeye, R. O. Akinyeye, I. Ogunlade, O. Olaofe, and J. O. Boluwade, "Effect of farm and industrial processing on the amino acid profile of cocoa beans," Food Chemistry, vol. 118, no. 2, pp. 357-363, 2010.

[51] Y. Alozie, M. I. Akpanabiatu, E. U. Eyong, I. B. Umoh, and G. Alozie, "Amino acid composition of Dioscorea dumetorum varieties," Pakistan Journal of Nutrition, vol. 8, no. 2, pp. $103-$ 105, 2009.

[52] N. C. Ihediohanma, N. C. Onuegbu, A. I. Peter-Ikechukwu, and N. C. Ojimba, "A comparative study and determination of glycemic indices of three yam cultivars (Dioscorea rotundata, Dioscorea alata and Dioscorea domentorum)," Pakistan Journal of Nutrition, vol. 11, no. 6, pp. 547-552, 2012.

[53] FAO/WHO/UNU, Energy and Protein Requirements, WHO Technical Report Series no. 724, World Health Organization, Geneva, Switzerland, 1985.

[54] E. I. Adeyeye and A. M. Kenni, “The relationship in the amino acid of the whole body, flesh and exoskeleton of common West African fresh water male crab Sudananautes africanus africanus," Pakistan Journal of Nutrition, vol. 7, no. 6, pp. 748752, 2008.

[55] E. I. Adeyeye, "Effect of cooking and roasting on the amino acid composition of raw groundnut (Arachis hypogaea) seeds," Acta Scientiarum Polonorum, Technologia Alimentaria, vol. 9, no. 2, pp. 201-216, 2010.

[56] D. K. Salunkhe and S. S. Kadam, Handbook of World Food Legumes, Nutritional Chemistry, Processing Technology and Utilization, CRC Press, Boca Raton, Fla, USA, 1989.

[57] E. A. Anyalogbu, E. N. Onyeike, and M. O. Monanu, "Amino acid profile of heat-processed Canarium schweinfurthii pulp," Journal of Scientific Research and Reports, vol. 3, no. 14, pp. 19731985, 2014.

[58] M. A. Oyarekua and A. F. Eleyinmi, "Comparative evaluation of the nutritional quality of corn, sorghum and millet ogi prepared by modified traditional technique," Food Agriculture Environment, vol. 2, pp. 94-99, 2004.

[59] C. O. Ibegbulem and P. C. Chikezie, "Serum lipid profile of rats (Rattus norvegicus) fed with palm oil and palm kernel oilcontaining diets," Asian Journal of Biochemistry, vol. 7, no. 1, pp. 46-53, 2012.

[60] W. Awoyale, B. M. Dixon, L. Sanni, and T. A. Shittu, "Nutritional and sensory properties of amala supplemented with Distiler's Spent Grain (DSG)," Journal of Food, Agriculture and Environment, vol. 8, no. 3-4, pp. 66-70, 2010.

[61] M. Olu, O. A. B. Ogunmoyela, O. O. Adekoyeni, O. Jimoh, S. O. Oluwajoba, and M. O. Sobanwa, "Rheological and functional properties of soy-poundo yam flour," International Journal of 
Food Science and Nutrition Engineering, vol. 2, no. 6, pp. 101-107, 2012.

[62] O. O. Ezekiel and O. C. Aworh, "Solid state fermentation of cassava peel with Trichoderma viride (ATCC 36316) for protein enrichment," International Scholarly and Scientific Research and Innovation, vol. 7, no. 3, pp. 202-209, 2013. 

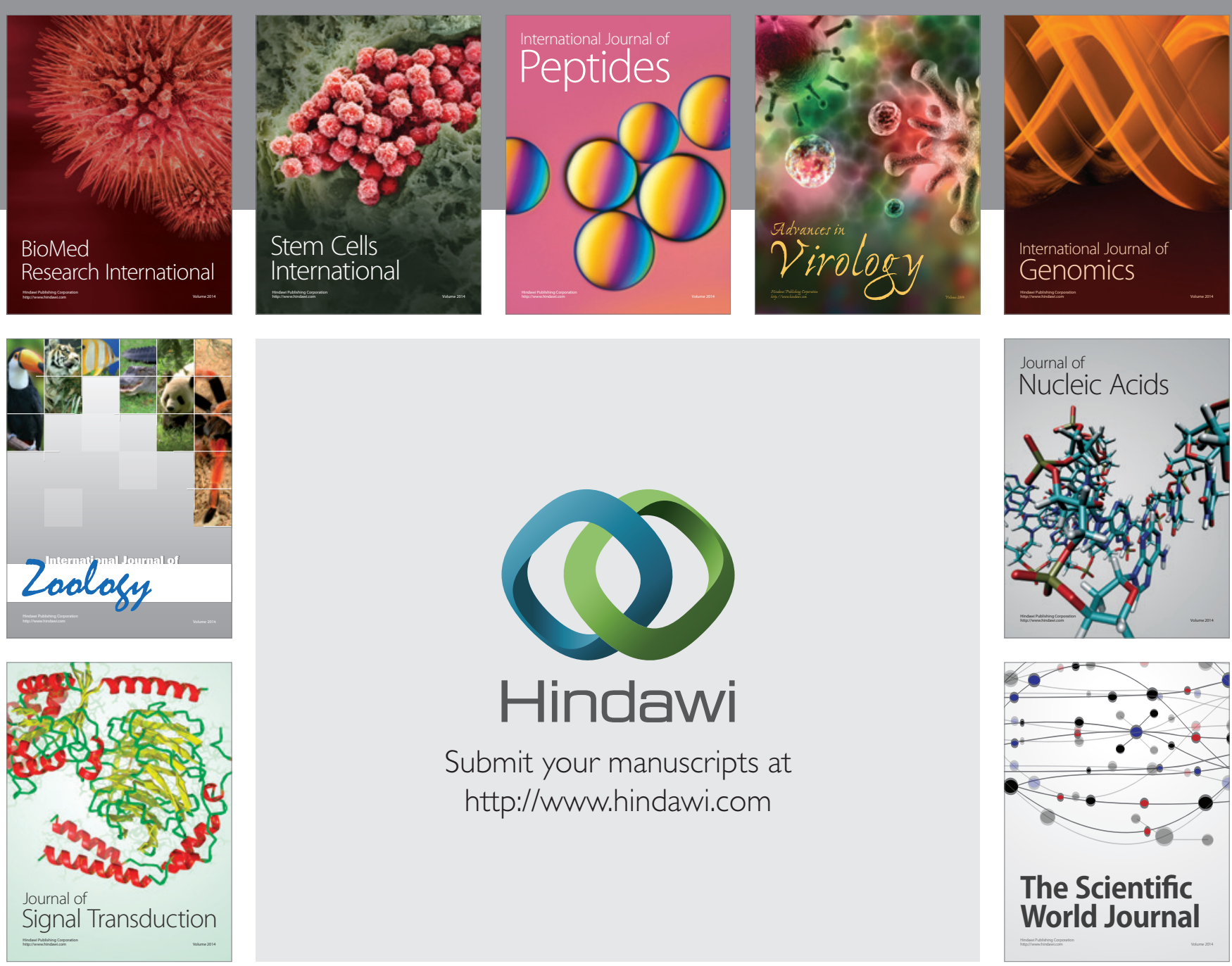

Submit your manuscripts at

http://www.hindawi.com
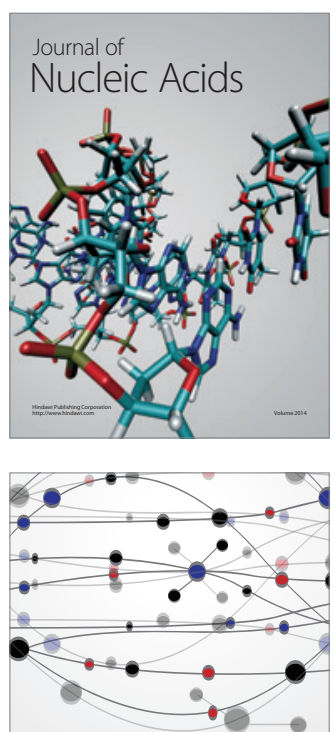

The Scientific World Journal
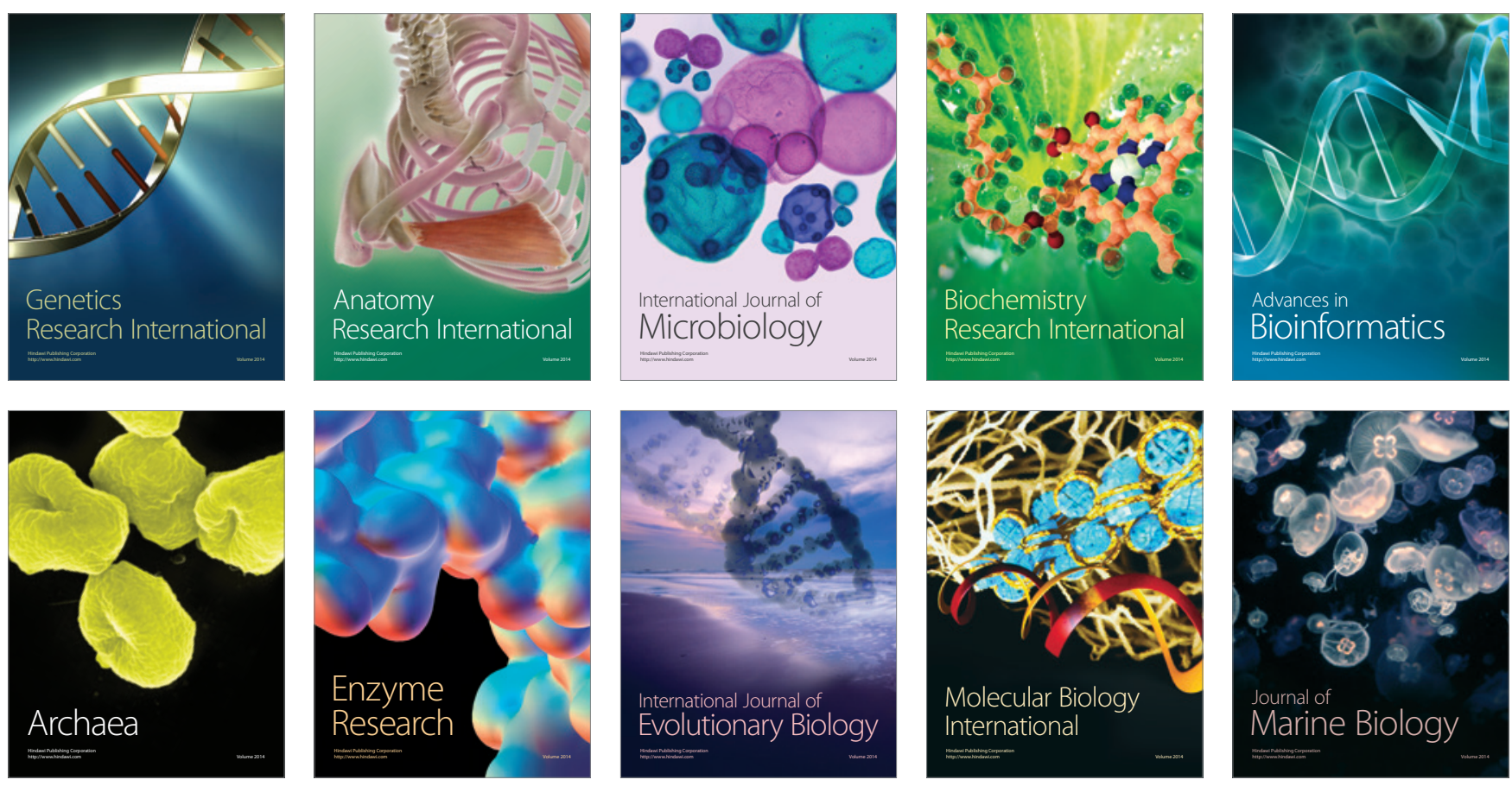